the effect that he stabbed his wife while she was asleep, and afterwards wounded himself.

Dr. Whitwell, of Shrewsbury, in cross-examination, said the prisoner, in his opinion, was snffering from epileptic mania, of which an irresistible homicidal impulse was one of the features.

By Lord Justice BraxweLL-By homicidal mania I mean a disposition to commit homicide. It is a kind of delusion.

Lord Justice Bramwgll-You mean a morbid appetite to do wrong.

Witness-I think the prisoner was acting under real or fancied provocation.

Lord Justice BramweLL, in samming up, said everybody was presumed to be sane until proved to be the contrary. Nor was it enough that a man was mad to entitle him to an acquittal. If an insane man knew he was committing murder that man was responsible. It was not enongh to have an homicidal mania. The object of the law was to gaard against mischievons propensities and homicidal impulses. A man might be suffering under a just sense of some grievous wroug or outrage which would impel him to violence, but that strong impulse, sane or insane, would not entitle him to an acquittal. He said this to the jury in order to disabuse their minds of a mischievous impression which existed, and which he believed had reached mad people themselves. He did not believe in uncontrollable impulse at all, and had never heard of such an impulse leading to action where the means of prevention were present. Having made these observations on what would not be sufficient grounds for an acquittal for insanity, his Lordship proceeded to tell the jury what, in his judgment, would be good grounds. A person would be not guilty on the ground of insanity if he did not know the nature of the act he was committing, or, if he did know it, if he did not know he was doing what was wrong. If a man stabbed another, and did not know he was inflicting hurt, that was insanity which the law recognised; and a person would not know that he was doing wrong unless he knew he was doing what the law forbade, or that his act was injurious to the person he attacked. His Lordship then referred to the evidence, pointing out the want of motive, and the absence of any indication of ill-will on the part of the prisoner against his wife, and observed that, undoubtedly, there were many circumstances in the case which would warrant the conclusion that he was insane in the sense he had pointed out.

The jury, withont leaving their box, said they found the prisoner not guilty on the ground of insanity.

Lord Justice BrAMWELL-It would have been impossible, gentlemen, for such a man to be executed-too shocking and cruel. It is a very sad case, and the man is deeply to be pitied. His Lordship then directed the prisoner to be retained during Her Majesty's pleasure, and the prisoner, who had preserved a calm, self-possessed manner throughout, was removed.-Times.

\title{
THE NEW COUNTY BOARDS BILL AS IT AFFECTS ASYLUMS.
}

In asking for leave to introduce the County Boards Bill in the Honse of Commons on the 18th March, Mr. Sclater-Booth made the following remarks in regard to how it would affect the Government of County Asylums. They show that the action of the Medico-Psycholugical Association last year has not been without result. "In the third place, the County Boards would have the very important power of reviewing the workhouse accommodation of each connty, and of providing for the accommodation in the workhouses of imbecile and idiot paupers, whether children or adults. He wished this power had been granted long ago. He did not provide in this Bill for any direct power over the lunatic asylums, but the Boards would be empowered to inquire into the lunatic asylums and enabled by their influence to check their future enlargement. It was proposed last year to give the County Boards a considerable share in the 
management of the lunatio asylums, and he had no doubt that before long some plan would be devised by which their management would be given to these County Boards. But long familiarity with the Publio Lunatio Aots had convinced him of the very great difficulty of dealing with those Aots by means of a few clauses in a Bill of this kind. It would be most nnsatisfactory, without a review of those Aots, to place the administration of the lanatio agylams in the hands of the County Boards."

\section{HEREDITARY SUICIDE.}

The son of M. Prevost Paradol, the eminent publicist and Minister of France to the United States, has committed suicide by blowing out his brains in the rooms of his tutor in the Rue Douai, Paris. No cause has been ascertained for the extraordinary act of the youth, who was only 17 years of age. It will be remembered that his father pat an end to his life in the same manner some years ago.

\section{Obituary.}

\section{D2. FOVILLE.}

The death of this distinguiched phydiclan, at Toulouse, on the 22nd of July, 1878, demands a briaf notice of his life und works. Wo feel this to be the more neceasary because his pen hes been wo long sheathed that there is some dunger of the present generation being lenorant of the good work which it once accomplished, and of the important position which he who wielded it once occupled. As a man, also deservedly respected and belored, his memory will long be cherished by those who knew hlm. For many years he was an Honorary mem Born at Pontols, the

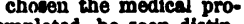
guished helf by his original researches into the anatomy and physlosy and the pathology of mental disorders. Thus, when he was only "Sur les Canses et la Siege des Maladies Mentales," which obtained the prize given by Bequirol. The in the articie "Folie," by Georget in the "Dictionnaire de Medicine"

The functions of the brain posseseed a great attraction for young Forllle, and co earily as 1823 ho published the "Recherches enr lo siffe special de diffurents fonctions dn systeme nerrens" in conjunction with Pinel Grandchamp. If apy one wrote now-a-days to eatabliah the fact that the brain is the seat of the intelligence, he would be ridiculed for asserting a platitide, but it was not 20 B8 Jears ago, and we find the anthor's first position is that intelligence and motion are functions of the encephalon. Going forther into detall in regard to the latter, he surmised that the corpus strit. tum presides over the movements of the lex, and the optic thalamns over those of the arm; also that the carebelium is the centre of sensation.

If these conclusions ahow how much adrance has been made in the physiology of the brain ince this treatise was written, they show also how early an investigator Fovillo was in this field of

inquiry. they without foundation? Certainly not. In the light of more recent recearches, and following Ferrier, the explanation may be thus expressed. Inasmuch as in cerebral paralyats the moet rolithonal movements are most affected, the arm is mere paralysed than the leg. Hence, in a lesion cansing paralysis more by functional interference than direct destruction of the motor tracts, the arm would be more arected than the leg; but in a lesion directly invading the motor part of the internal capsule, tho lecs as thell as tho an Would be maralysis in the the then the then, the vow the grounded on the absence confined to the corpus striatum then we shovld heve paral reis exretly limited to the arm- of which, however, proof has not been forthcoming. It is poeaible that in the leetons deweribed by Foville there may have been muny limited to the medullary fasciculi which have been ahown to be differentiated, and to have each their own special connection with the motor apparatus, whether of arm, leg, face, sc.

XXV. 